\title{
PERSEPSI PETANI ANGGOTA P3A TERHADAP PENGELOLAAN IRIGASI USAHATANI PADI SAWAH DI KELURAHAN MARGODADI KECAMATAN METRO SELATAN KOTA METRO
}

\author{
(The Perceptions of P3A Member Farmers on Irrigation Management of Rice Farming in Margodadi \\ Village South Metro Subdistrict Metro Regency)
}

Nadia Ulfa Armia, Dame Trully Gultom, Irwan Effendi

Jurusan Agribisnis, Fakultas Pertanian, Universitas Lampung, J1. Prof. Dr. Soemantri Brojonegoro No. 1 Bandar Lampung 35141, e-mail: dame.gultom@fp.unila.ac.id

\begin{abstract}
This study aims to determine the perceptions of P3A member farmers on irrigation management of rice farming and to analyze the factors related to the perception of the farmers on irrigation management of rice farming. This research was carried out in Margodadi Village South Metro Subdistrict Metro Regency with 65 respondents from P3A members participating in P3A activities. Data were collected through a survey method and analyzed descriptively and using nonparametric statistical tests of Spearman Rank Correlation. The results of this study indicated that the perceptions of P3A member farmers on irrigation management of rice farming is in the medium category. Factors related to the perceptions of P3A member farmers on irrigation management of rice farming are formal education, motivation, needs, rice farming experience, knowledge, social environment, support of related agencies, and land size. Meanwhile, unrelated factors are age and number of dependents.
\end{abstract}

Key words: field irrigation management, perceptions, P3A

\section{PENDAHULUAN}

Sebagian sistem irigasi di Indonesia dikembangkan untuk mengairi persawahan. Irigasi atau pengairan adalah suatu usaha mendatangkan air dengan membuat bangunan dan saluran-saluran ke sawahsawah atau ke ladang-ladang dengan cara teratur dan membuang air yang tidak diperlukan lagi (Prastowo 2010). Pembangunan saluran irigasi sangat diperlukan untuk menunjang penyediaan bahan pangan, sehingga ketersediaan air di daerah irigasi akan terpenuhi walaupun daerah irigasi tersebut berada jauh dari sumber air permukaan (sungai). Sawah irigasi merupakan faktor utama dalam pencapaian ketahanan pangan nasional.

Sejak Indonesia tidak mampu lagi mencapai swasembada pangan, berbagai perubahan kebijakan dilakukan pemerintah dalam pengelolaan irigasi. Kebijakan ini dituangkan dalam Inpres No.3/1999 tentang Pembaharuan Kebijakan Pengelolaan Irigasi (PKPI) yang memuat lima isi pokok yaitu redefinisi tugas dan tanggung jawab lembaga pengelola irigasi, pemberdayaan $\mathrm{P} 3 \mathrm{~A}$, penyerahan pengelolaan irigasi (PPI) kepada P3A, pembiayaan operasi pemeliharaan (OP) jaringan irigasi melalui iuran pelayanan air irigasi (IPAIR) dan keberlanjutan sistem irigasi. Luas lahan garapan petani sawah irigasi mempengaruhi produksi tanaman yang dihasilkan dan berpengaruh terhadap pendapatan yang diperoleh. Kota metro merupakan salah satu wilayah yang menggunakan saluran irigasi sebagai sarana penghubung antara sumber sir dan petak tanah pertanian atau persawahan. Anggota Perkumpulan Petani Pemakai Air (P3A) di Kota Metro memiliki ketergantungan dengan saluran irigasi karena mereka tidak dapat menanam padi jika tidak menggunakan saluran irigasi. P3A merupakan salah satu bentuk kelompok tani di tingkat desa, yang didirikan dengan tujuan mengatur dan mengelola pengairan (irigasi) pada lahan pertanian agar berjalan dengan baik dan teratur. P3A Ngudi Makmur memiliki daerah saluran irigasi terpanjang dan memiliki anggota terbanyak di Kota Metro.

Air irigasi merupakan salah satu sarana penting dalam budidaya pertanian untuk meningkatkan produksi pertanian dan pendapatan petani. Kecamatan Metro Selatan memiliki luas tanam 2.521 ha sawah yang merupakan salah satu lumbung padi nasional (BPS Kota Metro 2017). Luas tanam sawah yang besar memerlukan suplai debit air irigasi yang sangat besar, terukur dan konstan agar menjamin proses pola tanam bisa berjalan baik dan terkendali. Kebutuhan suplai air 
irigasi di Metro Selatan untuk sawah disalurkan melalui Bendungan Argoguruh yang memanfaatkan aliran Sungai Way Sekampung. Air irigasi disalurkan ke areal sawah yang berada di seluruh Daerah Irigasi (DI).

Seiring dengan perkembangan waktu, suplai dan kebutuhan akan air irigasi untuk mengairi areal sawah yang berada di Daerah Irigasi (DI) yang ada Kecamatan Metro Selatan mengalami perubahan yang sangat signifikan. Perubahan kondisi dimulai dari debit air Sungai Way Sekampung yang mengalami penurunan yang signifikan sehingga hal tersebut berdampak langsung pada debit air irigasi yang dikeluarkan melalui Bendungan Agroguroh. Perubahan kondisi lainnya adalah kondisi jaringan irigasi dan bangunan pelengkapnya yang ada di seluruh Daerah Irigasi yang ada di Metro Selatan. Mengingat luas areal sawah yang harus dilayani sangat luas, maka telah banyak kerusakan pada jaringan irigasi. Gejala kekurangan air irigasi dapat dilihat dari banyaknya tumbuhan di areal saluran irigasi, kerusakan pada aliran irigasi dan kebutuhan air banyak tetapi air tidak mencukupi.

Pengelolaan irigasi di Kelurahan Margodadi dilakukan oleh pengurus. Mengingat besarnya manfaat yang diperoleh dengan menerapkan kegiatan P3A maka penting untuk mengkaji persepsi petani terhadap pengelolaan irigasi usahatani padi sawah. Persepsi merupakan situasi setiap orang menginterprestasikan kondisi yang sama dengan cara yang berbeda dan setiap orang memiliki ekspektasi yang berbeda pula terhadap situasi yang sama, oleh karena itu penafsiran secara subjektif terhadap lingkungan akan menentukan bagaimana seseorang berperilaku (Mearn 2010).

Persepsi petani anggota P3A terhadap pengelolaan irigasi usahatani padi sawah bisa dilihat dari keberhasilan tujuan kegiatan P3A, jika persepsi petani baik atau positif maka kegiatan P3A akan berlanjut tetapi jika persepsi tidak baik atau negatif maka tidak akan bertlanjut kegiatannya. Pengelolaan irigasi dilakukan oleh pengurus bukan anggota P3A, jadi yang menilai baik atau buruknya pengelolaan irigasi yaitu petani anggota P3A. Persepsi seseorang akan menentukan bagaimana bentuk nyata penerapan pengelolaan irigasi di lapangan oleh orang tersebut, atau dengan kata lain persepsi dari petani yang mengikuti kegiatan P3A akan menentukan keberlanjutan kegiatan tersebut. Berdasarkan uraian tersebut, maka tujuan dari penelitian ini adalah mengetahui persepsi petani anggota P3A terhadap pengelolaan irigasi usahatani padi sawah dan menganalisis faktorfaktor apa sajakah yang berhubungan dengan persepsi petani anggota P3A terhadap pengelolaan irigasi usahatani padi sawah di Kelurahan Margodadi Kecamatan Metro Selatan Kota Metro.

\section{METODE PENELITIAN}

Penelitian ini dilakukan di Kelurahan Margodadi Kecamatan Metro Selatan Kota Metro. Lokasi penelitian dipilih secara sengaja (purposive) dengan pertimbangan bahwa Kota Metro merupakan salah satu sentra produksi bahan pangan di Provinsi Lampung dan sebagai wilayah yang melakukan kegiatan irigasi untuk usahatani padi sawah. Pengambilan data pada bulan September sampai November 2018. Populasi pada penelitian ini adalah 413 orang anggota petani yang melaksanakan kegiatan P3A, dari populasi tersebut jumlah sampel yang diperoleh sebanyak 65 responden yang ditetapkan berdasarkan rumus Sugiarto et al. (2003) dengan rumus sebagai berikut :

$$
\begin{aligned}
& \mathrm{n}=\frac{\mathrm{NZ}^{2} \mathrm{~S}^{2}}{\mathrm{Nd}^{2}+\mathrm{Z}^{2} \mathrm{~S}^{2}} \\
& \mathrm{n}=\frac{(413)\left(1,9 \wp^{2}(0,05)^{2}\right.}{413(0,05)^{2}+(1,96)^{2}(0,05)^{2}}=65 \text { orang }
\end{aligned}
$$

\section{Keterangan :}

$$
\begin{array}{ll}
\mathrm{n} & =\text { Jumlah sampel (org) } \\
\mathrm{N} & =\text { Jumlah populasi anggota P3A (413org) } \\
\mathrm{Z} & =\text { Tingkat kepercayaan }(95 \%=1,96)
\end{array}
$$

Sampel ditentukan secara simple random sampling. Metode penelitian yang digunakan adalah metode survey. Data yang digunakan dalam penelitian adalah data primer dan data sekunder. Data primer diperoleh melalui wawancara langsung dengan anggota P3A. Data sekunder diperoleh dari studi literatur terhadap dinas atau instansi terkait dan lembaga-lembaga yang berhubungan dengan penelitian ini.

Variabel $\mathrm{X}$ yaitu faktor-faktor yang diduga berhubungan dengan persepsi. Faktor-faktor tersebut ialah pendidikan formal, motivasi, kebutuhan, usia, pengalaman, jumlah tanggungan keluarga, pengetahuan terhadap P3A, lingkungan sosial, dukungan dinas terkait dan luas lahan. Variabel Y merupakan persepsi petani terhadap pengelolaan irigasi. Persepsi petani dilihat dari 
indikator pengelolaan irigasi yaitu operasi jaringan irigasi, pemeliharaan jaringan irigasi, pengamanan jaringan irigasi, rehabilitasi jaringan irigasi dan iuran jaringan irigasi. Pengukuran variabel $\mathrm{X}$ dan $\mathrm{Y}$ menggunakan teknik skoring yang diklasifikasikan ke dalam tiga kelas yaitu rendah, sedang dan tinggi.

Analisis data yang digunakan adalah metode analisis deskriptif kuantitatif untuk menjawab tujuan pertama dan inferensial untuk menjawab tujuan kedua. Tujuan kedua menggunakan statistik non parametrik uji korelasi Rank Spearman dengan SPSS 24.0 (Statistical Programs For Social Science). Adapun rumus uji korelasi Rank Spearman (Siegel 2011) adalah sebagai berikut:

$$
\mathrm{Rs}=1-\frac{6 \sum_{\mathrm{i}=1}^{\mathrm{n}} \mathrm{di}^{2}}{\mathrm{n}^{3}-\mathrm{n}}
$$

Keterangan :

Rs = Koefisien korelasi

di = Perbedaan pasangan setiap peringkat

$\mathrm{n} \quad=$ Jumlah sampel

Kaidah pengambilan keputusan adalah :

1. Jika $t$ hitung $<\mathrm{t}$ tabel, maka tolak $\mathrm{H} 1$ pada $(\alpha)$ $=0,05$. Artinya tidak terdapat hubungan yang nyata antara kedua variabel yang diuji.

2. Jika t hitung $\geq \mathrm{t}$ tabel, maka terima $\mathrm{H} 1$ pada $(\alpha)=0,05$. Artinya terdapat hubungan yang nyata antara kedua variabel yang diuji.

\section{HASIL DAN PEMBAHASAN}

\section{Identitas Responden}

Responden penelitian ini ialah petani yang mengikuti kegiatan P3A Kelurahan Margodadi Kecamatan Metro Selatan Kota Metro. Mayoritas umur responden adalah 55 tahun (92,30\%). Tingkat pendidikan yang ditempuh oleh responden mayoritas adalah pendidikan rendah ( $\leq 9$ tahun) yaitu $83,08 \%$.

Tingkat pendidikan yang rendah ini disebabkan biaya pendidikan formal yang masih relatif mahal bagi keluarga petani, sehingga sebagian besar keluarga petani putus sekolah. Mayoritas lama berusahatani padi responden adalah 22 tahun yaitu 31 orang $(47,69 \%)$.

Menurut Balinda (2012) semakin lama usahatani yang dilakukan maka semakin banyak pengalaman yang diperoleh. Mayoritas lama mengikuti P3A responden adalah 30 tahun yaitu 32 orang (49,23\%). P3A Ngudi Makmur di Kelurahan Margodadi sudah berdiri sejak tahun 1992. Ada beberapa petani yang belum resmi terdaftar sebagai anggota P3A di Dinas Pertanian Kota Metro.

\section{Persepsi Petani Terhadap Pengelolaan Irigasi}

Menurut Rakhmat (2007) persepsi adalah pengamatan tentang objek, peristiwa atau hubungan-hubungan yang diperoleh dengan menyimpulkan informasi dan menafsirkan pesan. Menurut Suharman (2005) persepsi merupakan suatu proses menginterpretasikan atau menafsir informasi yang diperoleh melalui sistem alat indera manusia. Menurutnya ada tiga aspek di dalam persepsi yang dianggap relevan dengan kognisi manusia, yaitu pencatatan indera, pengenalan pola, dan perhatian. Berdasarkan lima indikator persepsi petani terhadap pengelolaan irigasi dapat dilihat pada Tabel 1.

Berdasarkan data pada Tabel 1 sebanyak 31 petani (47,69\%) memiliki persepsi sedang terhadap pengelolaan irigasi. Hal ini menunjukkan bahwa manfaat dan pelaksanaan pengelolaan irigasi memberikan dampak yang positif kepada petani yaitu dengan meningkatkan hasil produksi dan pendampingan yang aktif sehingga mempermudah petani dalam menyampaikan keluhan atau kendala.

\section{Faktor-Faktor yang Diduga Berhubungan dengan Persepsi Terhadap Pengelolaan Irigasi}

Untuk melihat faktor-faktor yang berhubungan dengan persepsi maka dilakukan uji statistik. Hasil pengujian statistik terhadap faktor-faktor yang berhubungan dengan persepsi petani dapat dilihat pada Tabel 2.

\section{Hubungan antara pendidikan formal (X1) dengan persepsi petani terhadap pengelolaan irigasi usahatani padi sawah (Y)}

Ada hubungan yang nyata antara pendidikan formal dengan persepsi petani. Hal ini ditunjukkan dengan pengujian analisis korelasi Rank Spearman pada signifikan sebesar 0,038 dan taraf kepercayaan 95\%. Nilai t-hitung 3,541 lebih besar daripada t-tabel 1,989 artinya $\mathrm{H}_{1}$ diterima. Berdasarkan hasil penelitian yang memiliki pendidikan formal lebih tinggi cenderung memiliki persepsi yang lebih baik terhadap pengelolaan irigasi, hal tersebut karena wawasan dan pemikiran petani yang memiliki pendidikan formal lebih tinggi lebih terbuka daripada petani lainnya 
sehingga inovasi lebih mudah diterima dan diterapkan dalam pengelolaan irigasi usahatani padi sawah.

Petani di lokasi penelitian memiliki rata-rata pendidikan rendah, dengan pendidikan yang rendah tersebut petani cenderung memiliki persepsi yang rendah terhadap pengelolaaan irigasi karena sulit mengerti dan menerima inovasi tersebut. Menurut Ardiansyah, Sumaryo dan Helvi (2014) semakin tinggi pendidikan petani maka semakin baik persepsi terhadap suatu inovasi.

\section{Hubungan motivasi $\left(\mathrm{X}_{2}\right)$ dengan persepsi petani terhadap pengelolaan irigasi usahatani padi sawah (Y)}

Ada hubungan yang nyata antara motivasi dengan persepsi petani. Hal ini ditunjukkan dengan pengujian analisis korelasi Rank Spearman pada signifikan sebesar 0,000 dan taraf kepercayaan 99\%. Nilai t-hitung 10,846 lebih besar daripada ttabel 2,366 artinya $\mathrm{H}_{1}$ diterima.

Berdasarkan hasil penelitian di lapang, petani termotivasi melakukan kegiatan P3A karena adanya penyuluhan rutin dilakukan oleh penyuluh sehingga petani memiliki pengetahuan tentang pengelolaan irigasi usahatani padi sawah. Semakin tinggi motivasi maka semakin tinggi pula persepsi petani terhadap pengelolaan irigasi usahatani padi sawah.

\section{Hubungan kebutuhan $\left(\mathbf{X}_{3}\right)$ dengan persepsi petani terhadap pengelolaan irigasi usahatani padi sawah (Y)}

Ada hubungan yang nyata antara kebutuhan dengan persepsi petani. Hal ini ditunjukkan dengan pengujian analisis korelasi Rank Spearman pada signifikan sebesar 0,000 dan taraf kepercayaan 99\%. Nilai t-hitung 3,547 lebih besar daripada t-tabel 2,366 artinya $\mathrm{H}_{1}$ diterima. Hal ini disebabkan pemenuhan kebutuhan fisiologis (sandang, pangan, papan) petani dapat terpenuhi dengan baik, maka petani berharap dengan mengikuti P3A akan meningkatkan hasil produksi padi mereka sehingga pendapatan mereka meningkat. Kebutuhan petani responden berhubungan nyata dengan persepsi petani. Semakin tinggi kebutuhan maka semakin baik persepsi petani terhadap program SL-PHT usahatani kakao.

\section{Hubungan usia $\left(X_{4}\right)$ dengan persepsi petani} terhadap pengelolaan irigasi $(Y)$
Tidak ada hubungan yang nyata antara usia dengan persepsi petani. Hal ini ditunjukkan dengan pengujian analisis korelasi Rank Spearman pada signifikan sebesar 0,226 dan taraf kepercayaan 95\%. Nilai t-hitung 1,220 lebih besar daripada ttabel 1,989 artinya $\mathrm{H}_{1}$ ditolak. Umur seseorang mempengaruhi kerja fisik dan kematangan psikologisnya.

Responden dengan setengah baya cenderung yang paling tinggi adopsi inovasinya, karena kekuatan fisik dan kematangan psikologisnya saling mendukung. Apabila dilihat dari segi persepsi petani terhadap pengelolaan irigasi ternyata usia responden yang rata-rata masuk dalam klasifikasi setengah baya mempunyai persepsi yang kurang baik terhadap pengelolaan irigasi. Hal ini tidak berpengaruh terhadap persepsi petani, berapa pun usia responden maka persepsi yang dimiliki tetap berjalan baik. Hubungan antara usia dengan persepsi petani terhadap pengelolaan irigasi menggunakan analisis tabulasi silang dapat dilihat pada Tabel 3.

Tabel 3 menunjukkan adanya pengelompokkan data, baik pada variabel usia maupun variabel persepsi petani terhadap pengelolaan irigasi. Variabel usia berkelompok pada usia produktif dan variabel persepsi petani terhadap pengelolaan irigasi pada klasifikasi sedang. Petani responden yang memiliki usia sedang cenderung lebih responsif dalam menerima sesuatu yang baru, baik dari segi teknologi budidaya maupun mengenai pengelolaan irigasi.

Hubungan lama berusahatani $\left(X_{5}\right)$ dengan persepsi petani terhadap pengelolaan irigasi usahatani padi sawah (Y)

Ada hubungan yang nyata antara lama berusahatani dengan persepsi petani. Hal ini ditunjukkan dengan pengujian analisis korelasi Rank Spearman pada signifikan sebesar 0,000 dan taraf kepercayaan 99\%. Nilai t-hitung 12,861 lebih besar daripada t-tabel 2,366 artinya $\mathrm{H}_{1}$ diterima.

Berdasarkan hasil penelitian petani memiliki pengalaman yang berbeda-beda yang mereka rasakan selama berusahatani, namun melalui P3A membuat petani dapat mempelajari pengalaman usahatani padi dengan petani lain melalui diskusi yang diadakan minimal tiga kali dalam sebulan khususnya tentang kegiatan P3A dan pengelolaan irigasi usahatani padi sawah. Semakin lama usahatani petani maka semakin tinggi pula persepsi 
petani terhadap pengelolaan irigasi usahatani padi sawah.

\section{Hubungan jumlah tanggungan keluarga $\left(x_{6}\right)$ dengan persepsi petani terhadap pengelolaan irigasi usahatani padi sawah $(y)$}

Tidak ada hubungan yang nyata antara jumlah tanggungan keluarga dengan persepsi petani. Hal ini ditunjukkan dengan pengujian analisis korelasi Rank Spearman pada signifikan sebesar 0,435 dan taraf kepercayaan 95\%. Nilai t-hitung 0,5010 lebih besar daripada t-tabel 1,989 artinya $\mathrm{H}_{1}$ ditolak. Hal ini mengidentifikasi tidak ada hubungan antara jumlah tanggungan keluarga petani dengan persepsi petani terhadap pengelolaan irigasi.

Semakin tinggi atau semakin rendah jumlah tanggungan keluarga tidak ada hubungannya dengan persepsi petani terhadap pengelolaan irigasi. Secara keseluruhan anggota keluarga petani seperti anak-anaknya masih banyak yang masih sekolah dan kuliah sehingga beberapa rumah tangga petani lebih memfokuskan kegiatannya untuk mengurus anak-anak dan keluarganya. Hubungan antara jumlah tanggungan keluarga dengan persepsi petani terhadap pengelolaan irigasi menggunakan analisis tabulasi silang dapat dilihat pada Tabel 4 .

Tabel 4 menunjukkan adanya pengelompokkan data, baik pada variabel jumlah tanggungan keluarga maupun variabel persepsi petani terhadap pengelolaan irigasi. Variabel jumlah tanggungan keluarga berkelompok pada klasifikasi sedang dan variabel persepsi petani terhadap pengelolaan irigasi pada klasifikasi sedang, hal ini mengakibatkan data jumlah tanggungan keluarga tidak terdistribusi secara merata sehingga data yang didapat tidak bervariasi. Secara keseluruhan anggota keluarga petani seperti anak-anaknya masih banyak yang masih sekolah dan kuliah sehingga beberapa rumah tangga petani lebih memfokuskan kegiatannya untuk mengurus anakanak dan keluarganya.

\section{Hubungan pengetahuan informasi $\left(\mathrm{x}_{7}\right)$ dengan persepsi petani terhadap pengelolaan irigasi usahatani padi sawah $(y)$}

Ada hubungan yang nyata antara pengetahuan informasi dengan persepsi petani. Hal ini ditunjukkan dengan pengujian analisis korelasi Rank Spearman pada signifikan sebesar 0,001 dan taraf kepercayaan 99\%. Nilai t-hitung 3,630 lebih besar daripada t-tabel 2,366 artinya $\mathrm{H}_{1}$ diterima. Hal ini disebabkan oleh kesadaran pribadi yang tinggi. Kesadaran dalam mempengaruhi pengetahuan sangat penting mengingat seseorang bila tidak menyadari untuk memiliki keinginan tumbuh dan maju, seseorang tersebut akan mengalami keterlambatan dalam pengetahuan baik secara wawasan, pemikiran dan kemajuan dalam bidang lainnya.

Tingkat pengetahuan informasi dalam penelitian ini dilihat dari pengetahuan atau pemahaman petani tentang pengertian $\mathrm{P} 3 \mathrm{~A}$, tujuan $\mathrm{P} 3 \mathrm{~A}$ dan sasaran dari $\mathrm{P} 3 \mathrm{~A}$ yang mudah untuk diingat dan dipahami oleh petani. Pengertian P3A yang diketahui oleh petani adalah Perkumpulan Petani Pemakai Air. Tujuan P3A yang diketahui oleh petani yaitu mendayagunakan potensi air irigasi yang tersedia didalam petak tersier atau daerah irigasi pedesaan untuk kesejahteraan masyarakat petani.

Tabel 2. Hasil pengujian statistik terhadap faktor-faktor yang berhubungan dengan persepsi petani

\begin{tabular}{|c|c|c|c|c|c|}
\hline No & Variabel X & Variabel Y & $\begin{array}{c}\text { Koefisien } \\
\text { korelasi (rs) }\end{array}$ & $\begin{array}{l}\text { Sig. (2- } \\
\text { tailed) }\end{array}$ & $\begin{array}{c}\mathrm{t}- \\
\text { hitung }\end{array}$ \\
\hline 1 & Pendidikan formal $\left(\mathrm{X}_{1}\right)$ & & $-0,258 *$ & 0,038 & 3,541 \\
\hline 2 & Motivasi $\left(\mathrm{X}_{2}\right)$ & & $0,807 * *$ & 0,000 & 10,846 \\
\hline 3 & Kebutuhan $\left(\mathrm{X}_{3}\right)$ & & $0,449 * *$ & 0,000 & 3,547 \\
\hline 4 & Usia $\left(X_{4}\right)$ & & $0,152^{\text {tn }}$ & 0,226 & 1,220 \\
\hline 5 & Lama berusahatani $\left(\mathrm{X}_{5}\right)$ & Persepsi petani & $0,851 * *$ & 0,000 & 12,861 \\
\hline 6 & Jumlah tanggungan keluarga $\left(\mathrm{X}_{6}\right)$ & $\begin{array}{l}\text { terhadap pengelolaan } \\
\text { irigasi }\end{array}$ & $-0,099^{\operatorname{tn}}$ & 0,435 & 0,5010 \\
\hline 7 & Pengetahuan terhadap informasi $\left(\mathrm{X}_{7}\right)$ & & $0,416^{* *}$ & 0,001 & 3,630 \\
\hline 8 & Lingkungan sosial $\left(\mathrm{X}_{8}\right)$ & & $0,478 * *$ & 0,000 & 4,319 \\
\hline 9 & Dukungan dinas terkait $\left(\mathrm{X}_{9}\right)$ & & $0,549 * *$ & 0,000 & 5,213 \\
\hline 10 & Luas lahan $\left(\mathrm{X}_{10}\right)$ & & $0,808 * *$ & 0,000 & 10,808 \\
\hline
\end{tabular}

**: Nyata pada taraf kepercayaan $99 \%(\mathrm{t}$ tabel $=2,366)$

$* \quad$ : Nyata pada taraf kepercayaan $95 \%(\mathrm{t}$ tabel $=1,989)$

tn : Tidak nyata pada taraf kepercayaan $95 \%$ 
Tabel 3. Hubungan antara usia dengan persepsi petani terhadap pengelolaan irigasi

\begin{tabular}{ccccc}
\hline \multirow{2}{*}{ Persepsi } & & Usia & & $\begin{array}{c}\text { Total } \\
(\text { Orang) }\end{array}$ \\
\cline { 2 - 5 } & Muda & Sedang & Tua & \\
\hline Rendah & 0 & 3 & 3 & 6 \\
Sedang & 0 & 30 & 1 & 31 \\
Tinggi & 0 & 27 & 1 & 28 \\
\hline Total & 0 & 60 & 5 & 65 \\
\hline
\end{tabular}

Tabel 4. Hubungan antara jumlah tanggungan keluarga dengan persepsi petani terhadap pengelolaan irigasi

\begin{tabular}{|c|c|c|c|c|}
\hline \multirow[t]{2}{*}{ Persepsi } & \multicolumn{3}{|c|}{$\begin{array}{c}\text { Jumlah tanggungan } \\
\text { keluarga }\end{array}$} & \multirow{2}{*}{$\begin{array}{c}\text { Total } \\
\text { (Orang) }\end{array}$} \\
\hline & Rendah & Sedang & Tinggi & \\
\hline Rendah & 0 & 5 & 1 & 6 \\
\hline Sedang & 11 & 16 & 4 & 31 \\
\hline Tinggi & 9 & 15 & 4 & 28 \\
\hline Total & 20 & 36 & 9 & 65 \\
\hline
\end{tabular}

Sasaran P3A yang diketahui oleh petani yaitu dapat memecahkan masalah dan meredakan konflik pembagian air. Menurut Musoleha, Tubagus dan Indah (2014) masyarakat yang berpengetahuan rendah hanya mengetahui sebagian kecil dari pelaksanaan PKBL, responden beranggapan bahwa program yang diberikan kurang bermanfaat dan tidak semua masyarakat dapat menikmati hasil program tersebut. Masyarakat yang memiliki pengetahuan tinggi terhadap program-program yang dilaksanakan perusahaan beranggapan bahwa PKBL sangat bermanfaat bagi masyarakat dan lingkungan sekitar. Semakin tinggi tingkat pengetahuan maka semakin baik persepsi masyarakat terhadap program PKBL.

Hubungan dukungan dinas terkait $\left(\mathrm{X}_{9}\right)$ dengan persepsi petani terhadap pengelolaan irigasi usahatani padi sawah (Y)

Ada hubungan yang nyata antara dukungan dinas terkait dengan persepsi petani. Hal ini ditunjukkan dengan pengujian analisis korelasi Rank Spearman pada signifikan sebesar 0,000 dan taraf kepercayaan 99\%. Nilai t-hitung 5,213 lebih besar daripada t-tabel 2,366 artinya $\mathrm{H}_{1}$ diterima. Semakin baik dukungan instansi maka akan mempengaruhi persepsi petani terhadap pengelolaan irigasi usahatani padi sawah.

Hal ini disebabkan oleh dukungan yang diberikan pendamping kepada petani berupa kehadiran pendamping (PPL) dalam setiap perkumpulan di kelompok P3A, memberikan materi penyuluhan yang jelas serta sesuai dengan kebutuhan petani sehingga petani dapat menaganggulangi kendala yang terjadi pada usahataninya serta mendapat banyak pengetahuan baru untuk meningkatkan usahataninya. Semakin tinggi dukungan dinas terkait maka semakin tinggi pula persepsi petani terhadap pengelolaan irigasi usahatani padi sawah.

\section{Hubungan luas lahan $\left(\mathrm{X}_{10}\right)$ dengan persepsi petani terhadap pengelolaan irigasi usahatani padi $\operatorname{sawah}(\mathbf{Y})$}

Ada hubungan yang nyata antara luas lahan dengan persepsi petani. Hal ini ditunjukkan dengan pengujian analisis korelasi Rank Spearman pada signifikan sebesar 0,000 dan taraf kepercayaan 99\%. Nilai t-hitung 10,808 lebih besar daripada ttabel 2,366 artinya $\mathrm{H}_{1}$ diterima. Semakin luas lahan yang dimiliki petani semakin baik pula persepsi petani terhadap pengelolaan irigasi. Kondisi di lapangan menyatakan bahwa luas lahan padi sawah petani di Kelurahan Margodadi Kecamatan Metro Selatan adalah 0,18-2,16 hektar. Hal ini harus diatasi dengan memaksimalkan penggunaan lahan pada usahatani padi petani tersebut. Besarnya luas lahan sangat menentukan produksi yang dicapai. Luas lahan yang dimiliki petani akan mempengaruhi waktu luang dan tenaga yang digunakan dalam berusahatani. Semakin luas lahan yang digarap maka semakin sempit waktu luang yang dimiliki petani karena semakin besar tenaga yang diperlukan dalam berusahatani. Semakin tinggi luas lahan maka semakin tinggi pula persepsi petani terhadap pengelolaan irigasi usahatani padi sawah.

\section{KESIMPULAN}

Persepsi petani anggota P3A terhadap pengelolaan irigasi usahatani padi sawah masuk dalam kategori sedang. Faktor-faktor yang berhubungan dengan persepsi petani anggota P3A terhadap pengelolaan irigasi usahatani padi sawah adalah pendidikan formal (X1), motivasi (X2), kebutuhan (X3), lama berusahatani (X5), pengetahuan terhadap P3A (X7), lingkungan sosial (X8), dukungan dinas terkait (X9), luas lahan (X10). Faktor-faktor yang tidak berhubungan dengan persepsi petani anggota P3A terhadap pengelolaan irigasi usahatani padi sawah adalah usia (X4) dan jumlah tanggungan keluarga (X6). 


\section{DAFTAR PUSTAKA}

Ardiansyah A, Sumaryo G, dan Helvi Y. 2014. Persepsi petani terhadap kinerja penyuluh di BP3K sebagai Model Center of Excellence (CoE) Kecamatan Metro Barat Kota Metro. JIIA, 2(2): 182-189. http://jurnal.fp. unila.ac.id/index.php/JIA/article/view/743. [10 November 2019].

Balinda N. 2012. Respon petani Apel terhadap industrialisasi pertanian (Kasus di Desa Poncokusumo, Kecamatan Poncokusumo, Kabupaten Malang). SEPA, 8(2): 92-103. http://agribisnis.fp.uns.ac.id/wpcontent luploads/106. [17 September 2019].

Badan Pusat Statistik [BPS] Kota Metro. 2017. Luas Tanam, Panen dan Produksi Padi 2017. https://metrokota.bps.go.id. [10 Maret 2018].

Mearns J. 2010. The Social Learning Theory of Julian B. Rotter. http://psych.fullerton. edu/jmearns/rotter.html. [26 April 2018].
Musoleha T, Tubagus H, dan Indah L. 2014. Persepsi masyarakat terhadap program Kemitraan Dan Bina Lingkungan (PKBL) PTPN VII Unit Usaha Rejosari Kecamatan Natar Kabupaten Lampung Selatan. JIIA, 2 (4): 394-401. http://jurnal.fp.unila.ac.id lindex.php/JIA/article/view/994/899. [10 November 2019].

Siegel S. 2011. Statistik Non-Parametrik Ilmu-ilmu Sosial. PT Gramedia. Pustaka Utama. Jakarta.

Prastowo. 2010. Irigasi Tetes. Teori dan Aplikasi. IPB. Bogor.

Rakhmat J. 2007. Psikologi Komunikasi. Remaja Rosdakarya. Bandung.

Sugiarto D, Sunaryanto S, dan Oetomo DS. 2003. Teknik Sampling. Gramedia Pustaka Utama. Jakarta.

Suharman. 2005. Psikologi Kognitif. Srikandi. Surabaya. 